\title{
Mentholated cigarettes and smoking habits in whites and blacks
}

\author{
J E Muscat, J P Richie Jr, S D Stellman
}

Tobacco Control 2002;11:368-371

See end of article for authors' affiliations

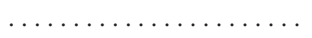

Correspondence to: Joshua E Muscat, American Health Foundation, One Dana Road, Valhalla, New York 10595, USA; jmuscat@ahf.org

Received 8 May 2002 and revision requested

5 September 2002.

Accepted 24 September 2002

\begin{abstract}
Objective: To determine if cigarette mentholation is associated with the frequency of smoking and with quitting, and whether mentholation explains racial differences in these two smoking behaviours.

Design: Cross sectional analysis of case-control data on smoking and lung cancer. Subjects: Limited to 19545 current and former cigarette smokers.

Main outcome measures: Smoking $>20$ cigarettes per day (cpd) versus $\leqslant 20 \mathrm{cpd}$, and continued smoking versus quit smoking.

Results: Among blacks, the prevalence odds ratio (POR) of heavy smoking ( $\geqslant 21 \mathrm{cpd}$ ) associated with mentholated cigarettes versus non-mentholated cigarettes was 0.7 (95\% confidence interval (Cl) 0.5 to $0.9)$ in current smokers and $0.6(95 \% \mathrm{Cl} 0.4$ to 0.9$)$ in former smokers. Among whites, the corresponding POR were $0.9(95 \% \mathrm{Cl} 0.8$ to 1.0$)$ and $0.9(95 \% \mathrm{Cl} 0.8$ to 1.0$)$. Blacks were less likely to have been heavy smokers than whites, but the difference was unrelated to cigarette mentholation. The POR of continued smoking versus quitting, associated with mentholated cigarettes was $1.1(95 \% \mathrm{Cl} 1.0$ to 1.2) for both blacks and whites.

Conclusion: Smoking > 20 cpd was independently associated with white race. Among blacks, smoking $\leqslant 20 \mathrm{cpd}$ was independently associated with mentholated cigarettes. The risk of quitting was not associated with cigarette menthol flavour.
\end{abstract}

M enthol is the only cigarette additive that is advertised and promoted. It is a flavouring agent that is sprayed on tobacco and offsets the heat sensation during smoking by stimulating cold receptors. Menthol is the chief constituent of peppermint oil and is found in many oral hygiene products, medications, skin lotions, and candy. It is regulated as a food and drug additive but not as a cigarette additive. Menthol increases salivary flow and acts as a bronchodilator. Although mentholated cigarettes were first sold to the public in the 1920s, menthol market share remained low until the 1960s and now accounts for about $25 \%$ of all cigarettes sold domestically in the USA. The increase in the popularity of menthol is likely due to advertising that promotes its association with good health. It has become the most commonly smoked brand of cigarette among young African Americans (blacks), but is also smoked by other racial and ethnic groups. ${ }^{1-3}$ However the health effects from smoking mentholated cigarettes have not been systematically studied. Smokers of mentholated cigarettes take fewer puffs but expire higher levels of carbon monoxide. ${ }^{4-7}$ It has been hypothesised that the higher mortality rate of smoking related cancers among blacks is due to menthol although several studies found little or no risk. ${ }^{8-12}$

A fundamental question concerning mentholated cigarettes and health is whether the number of cigarettes smoked per day (cpd) and the rate of quitting vary by menthol flavouring. There are little data on whether the lower quit rate and cpd in blacks ${ }^{13-15}$ versus whites is due to their preference for mentholated cigarettes. In one study, the average number of cigarettes smoked per day was $16.2 \mathrm{cpd}$ among smokers of mentholated cigarettes and $17.1 \mathrm{cpd}$ for smokers of non-mentholated cigarettes, although race specific figures were not determined. ${ }^{1}$ This difference could be due to the higher nicotine content in mentholated cigarettes. ${ }^{17}$ The preference for high nicotine menthol cigarettes among blacks could reflect their lower amounts of smoking. In active smokers, higher concentrations of blood cotinine have been found in blacks than in whites after controlling for $\mathrm{cpd} .{ }^{17-19}$
Menthol might directly produce its own addicting effect or increase the reinforcing effects of nicotine. Menthol could potentially facilitate addiction by its sensory effects or its perceived qualities as a healthy substance. In one study of 36 smokers, menthol smokers had increased craving relative to non-menthol smokers. ${ }^{20}$ The possibility that menthol could be a factor associated with the lower quit rate among black smokers remains unexplored. Successful quitters smoke fewer cigarettes per day, at least in some studies, ${ }^{152} 22$ yet blacks are less likely to quit than whites despite smoking fewer cigarettes per day.

The smoking habits of almost 20000 white and black smokers were analysed to determine whether the daily consumption of cigarettes and the quit rate were associated with cigarette menthol content.

\section{METHODS}

The subjects for this cross sectional analysis were current and former smokers who participated in a case-control study of tobacco related cancers. The original study was conducted to determine the relation between the dose of cigarette exposure and lung, head and neck, kidney, and pancreas cancers. In particular, the risk was studied in relation to cigarette formulation, occupation, social class, and diet. ${ }^{23}$ For example, it was reported that the histologic specific risk of lung cancer depended on the cigarette "tar" yield. ${ }^{24}$ Cigarette additives were also hypothesised to affect the risk of aerodigestive cancers, although no association was observed with the use of mentholated cigarettes (compared to non-mentholated cigarettes)..$^{8-10}$

The study was conducted in several hospitals in New York, Washington, DC and Pennsylvania between 1981 and 1999. Newly diagnosed cancer patients were identified from thoracic and other surgery schedules. Non-surgical patients were sought out in oncology wards. Pathology reports were obtained to

Abbreviations: $\mathrm{Cl}$, confidence interval; $\mathrm{cpd}$; cigarettes per day; FTC, Federal Trade Commission; POR, prevalence odds ratio 


\begin{tabular}{|c|c|c|c|c|c|c|}
\hline & \multicolumn{2}{|l|}{ Black } & \multirow[b]{2}{*}{$p$ Value } & \multicolumn{2}{|l|}{ White* } & \multirow[b]{2}{*}{$\mathrm{p}$ Value } \\
\hline & $\begin{array}{l}\text { Non-menthol (\%) } \\
(n=1251)\end{array}$ & $\begin{array}{l}\text { Menthol }(\%) \\
(n=655)\end{array}$ & & $\begin{array}{l}\text { Non-menthol (\%) } \\
(n=15289)\end{array}$ & $\begin{array}{l}\text { Menthol }(\%) \\
(n=2350)\end{array}$ & \\
\hline \multicolumn{7}{|l|}{ Sex } \\
\hline Male & $860(68.8)$ & $415(63.4)$ & & $10881(71.2)$ & $1526(64.9)$ & \\
\hline Female & $391(31.3)$ & $240(36.6)$ & $<0.02$ & $4408(28.8)$ & $824(35.1)$ & $<0.01$ \\
\hline \multicolumn{7}{|l|}{ Age (years) } \\
\hline$<45$ & $88(7.0)$ & $109(16.6)$ & & 1158 (7.6) & 257 (10.9) & \\
\hline $45-54$ & $296(23.7)$ & $180(27.5)$ & & $3076(20.2)$ & $591(25.2)$ & \\
\hline $55-64$ & $532(42.5)$ & $238(36.3)$ & & 5895 (38.6) & $874(37.2)$ & \\
\hline$\geqslant 65$ & $335(26.8)$ & $128(19.5)$ & $<0.01$ & $5160(33.8)$ & $628(26.7)$ & $<0.01$ \\
\hline \multicolumn{7}{|l|}{ Subjects } \\
\hline Controls & $453(36.2)$ & $257(39.2)$ & & 6459 (42.3) & $997(42.4)$ & \\
\hline Cases & $798(63.8)$ & $398(60.8)$ & NS & $8830(57.8)$ & $1353(57.6)$ & NS \\
\hline \multicolumn{7}{|l|}{ Smoking } \\
\hline Current & $804(64.3)$ & $461(70.4)$ & & 7201 (47.1) & $1323(56.3)$ & \\
\hline Former & 447 (35.7) & $194(29.4)$ & $<0.01$ & 8088 (52.9) & 1027 (43.7) & $<0.01$ \\
\hline \multicolumn{7}{|c|}{ Cigarettes per day } \\
\hline $1-10$ & $374(29.9)$ & $226(34.5)$ & & 2279 (14.9) & $424(18.1)$ & \\
\hline $11-20$ & $519(41.5)$ & $294(44.9)$ & & 5195 (34.0) & $780(33.2)$ & \\
\hline $21-39$ & $167(13.4)$ & $77(11.8)$ & & 2814 (18.4) & 407 (17.3) & \\
\hline$\geqslant 40$ & 191 (15.3) & $58(8.9)$ & $<0.01$ & $4972(32.6)$ & 737 (31.4) & $<0.01$ \\
\hline
\end{tabular}

confirm the diagnoses and medical reports were reviewed to ensure that the patient had no previous history of lung cancer. Control patients with medical conditions unrelated to cigarette smoking were frequency matched to the cases by age (within five years), sex, race, hospital, and month of interview. Controls were selected randomly from general hospital admitting rosters. Annual refusal rates were always below 15\%. All subjects signed a consent form that was approved by the institutional review boards of the participating institutions. All subjects were administered a structured questionnaire which contained detailed items on smoking history previous to the diagnosis. The questions included years of smoking and cigarettes per day for each cigarette brand smoked. Information on menthol content (for example, menthol $v$ unflavoured) was also obtained.

The current analysis was limited to current and former cigarette smokers, and black and white subjects. Ever smokers were defined as having smoked at least one cigarette each day for one year. Current smokers were subjects that smoked at least one cigarette each day for the preceding year. Ex-smokers were ever smokers who did not smoke at least one cigarette each day for the preceding year. Because the same percentage of cases and controls reported smoking mentholated cigarettes, cases and controls were grouped together in the statistical analyses. Most subjects who smoked mentholated cigarettes during their lifetime also had smoked nonmentholated cigarettes. Therefore subjects were classified as a menthol smoker if the last brand of cigarette smoked (for both current and former smokers) was mentholated.

The data were analysed using SAS software (SAS Institute, Cary, North Carolina). Descriptive statistics included frequencies and percentages of nominal data, and means and standard deviations of continuous data. $\chi^{2}$ Tests were conducted to determine differences in subject characteristics between menthol and non-menthol smokers. Unconditional logistic regression was used to calculate the prevalence odds ratio (POR) and 95\% confidence intervals (CI). The outcome variable was smoking status (current $v$ quit). The independent variables included case-control status, age, sex, race, education, cpd, years of smoking, cigarette menthol content, and body mass index. The POR was also calculated for cigarette amount (for example, $>20 \mathrm{cpd} v \leqslant 20 \mathrm{cpd}$ ). The same analyses were repeated for control subjects only. The POR was further calculated separately by three time intervals (for example, 1980 to 1984,1985 to 1990,1991 to 1999) to determine whether there were temporal changes in the relation between menthol and smoking habits.

\section{RESULTS}

There were 19545 subjects, including 16540 (84.6\%) smokers of non-mentholated cigarettes and 3005 (15.4\%) smokers of mentholated cigarettes. Eleven per cent of subjects were black. Using $\chi^{2}$ analyses, significant differences were found in the use of mentholated cigarettes by sex, age, smoking status, and cigarettes per day (table 1). Smokers of mentholated cigarettes were significantly more likely to have been women (blacks: $36.6 \%$ v $31.3 \%$; whites: $35.1 \% \vee 28.8 \%$ ), less than 55 years of age (blacks: $44.1 \%$ v 30.7\%; whites: $36.1 \%$ v $27.8 \%$ ), former smokers (blacks), and smoked fewer cigarettes per day (blacks: 18.2 $v$ 20.9; whites: $28.1 v 28.9$ ). There were no differences in the percentage of cases and controls who smoked menthol. For smokers of non-mentholated cigarettes, the mean number of years of smoking was 34.8 for blacks and 32.4 for whites. For smokers of mentholated cigarettes, the mean number of years of smoking was 31.7 for blacks and 33.0 for whites.

Comparing smoking habits between blacks and whites, blacks preferred mentholated cigarettes $(34.4 \%$ v $13.3 \%$, $\mathrm{p}<0.01)$ and were more likely to have been current smokers (66.4\% v 48.3\%, p < 0.01). Whites smoked more cigarettes per day than blacks (men: $30.6 \mathrm{cpd} v 20.2 \mathrm{cpd}$, p < 0.01; women: $24.0 \mathrm{cpd} v 16.6 \mathrm{cpd}, \mathrm{p}<0.01)$.

The POR of smoking $\geqslant 21 \mathrm{cpd}$ associated with mentholated cigarettes was 0.7 (95\% CI 0.5 to 0.9 ) in blacks who currently smoked and 0.9 (95\% CI 0.8 to 1.0 ) in whites who currently smoked (table 2). Very similar findings were observed in former smokers. Blacks were less likely than whites to smoke more than one pack per day, after adjustment for menthol content, smoking status, and other covariates (POR 0.30, 95\% CI 0.27 to 0.34 ). In an analysis limited to control subjects, the findings were nearly identical (data not shown). There were little differences in the POR by time interval, except for a stronger relation among blacks in the most recent time period. For current smokers, the POR was 0.8 (95\% CI 0.4 to 1.2 ) for the early time period, 0.8 ( $95 \%$ CI 0.5 to 1.2 ) for the middle period, and 0.3 ( $95 \%$ CI 0.2 to 0.7 ) for the late time period. For former smokers the POR was 0.8 (95\% CI 0.3 to 2.0$), 0.9$ (95\% CI 0.5 to 1.5 ), and 0.2 ( $95 \%$ CI 0.1 to 0.7 ), respectively. 
Table 2 Prevalence odds ratio (POR) for smoking $\geqslant 21$ cigarettes per day (cpd) versus smoking $\leqslant 20 \mathrm{cpd}$ associated with cigarette menthol content

\begin{tabular}{|c|c|c|c|c|c|c|c|c|}
\hline \multirow{2}{*}{$\begin{array}{l}\text { Cigarette } \\
\text { flavouring }\end{array}$} & \multicolumn{4}{|l|}{ Blacks } & \multicolumn{4}{|l|}{ Whites } \\
\hline & Mean (SD) cpd & $\geqslant 21 \mathrm{cpd}(\%)$ & $\leqslant 20 \mathrm{cpd}(\%)$ & POR $(95 \% \mathrm{Cl})^{*}$ & Mean (SD) cpd & $\geqslant 21 \mathrm{cpd}(\%)$ & $\leqslant 20 \mathrm{cpd}(\%)$ & POR $(95 \% \mathrm{Cl})^{*}$ \\
\hline \multicolumn{9}{|l|}{ Current smokers } \\
\hline Non-menthol & 20.9 (12.7) & $234(70.9)$ & $570(61.0)$ & 1.0 & $29.3(15.4)$ & 3895 (85.4) & 3300 (83.4) & 1.0 \\
\hline Menthol & $18.2(10.8)$ & $96(29.1)$ & 365 (39.0) & 0.7 (0.5 to 0.9$)$ & $28.0(15.5)$ & $667(14.6)$ & $656(16.6)$ & 0.9 (0.8 to 1.0$)$ \\
\hline \multicolumn{9}{|l|}{ Former smokers } \\
\hline Non-menthol & $21.0(15.4)$ & $124(76.1)$ & $323(67.6)$ & 1.0 & $28.6(18.3)$ & 3891 (89.1) & $4174(88.4)$ & 1.0 \\
\hline Menthol & $18.0(12.6)$ & 39 (23.9) & 155 (32.4) & $0.6(0.4$ to 0.9$)$ & $28.2(19.3)$ & 477 (10.9) & $548(11.6)$ & $0.9(0.8$ to 1.0$)$ \\
\hline
\end{tabular}

Table 3 Prevalence odds ratios (POR) for currently smoking versus quitting associated with cigarette menthol content

\begin{tabular}{|c|c|c|c|c|c|c|}
\hline & \multicolumn{3}{|l|}{ Black } & \multicolumn{3}{|l|}{ White } \\
\hline & $\begin{array}{l}\text { Current } \\
\text { smoker (\%) }\end{array}$ & $\begin{array}{l}\text { Former } \\
\text { smoker (\%) }\end{array}$ & POR $(95 \% \mathrm{Cl})^{*}$ & $\begin{array}{l}\text { Current } \\
\text { smoker (\%) }\end{array}$ & $\begin{array}{l}\text { Former } \\
\text { smoker (\%) }\end{array}$ & POR $(95 \% \mathrm{Cl})^{*}$ \\
\hline \multicolumn{7}{|c|}{ Cigarette flavouring } \\
\hline Non-menthol & $804(63.6)$ & $447(69.7)$ & 1.0 & 7201 (84.5) & 8088 (88.7) & 1.0 \\
\hline Menthol & $461(36.4)$ & $194(30.3)$ & 1.1 (0.8 to 1.4$)$ & 1323 (18.7) & 1027 (11.3) & 1.1 (1.0 to 1.3 ) \\
\hline
\end{tabular}

Cigarette mentholation was not associated with continued smoking. The POR was 1.1 (95\% CI 0.8 to 1.4 ) in blacks and 1.1 (95\% CI 1.0 to 1.2 ) in whites (table 3 ). Blacks were more likely to have been current smokers than whites for both men (POR $1.4,95 \%$ CI 1.2 to 1.7 ) and women (POR $1.3,95 \%$ CI 1.1 to 1.7 ) (table 4). The findings from analyses limited to the control subjects were nearly identical to analyses based on cases and controls combined. When stratified by time period, there were few differences in the POR.

The independent predictors of currently smoking and smoking more than one pack per day are shown in table 4 . In a model that simultaneously adjusted for sex, race, age, and other covariates, the association with menthol was consistent with previous analyses. Menthol was not associated with continued smoking, and was inversely associated with smoking more than one pack per day.

\section{DISCUSSION}

The findings from this study are consistent with another survey showing that smokers of mentholated cigarettes consume fewer cigarettes per day. ${ }^{1}$ Our data show that this relation is more pronounced in blacks, which could reflect a higher nicotine content among the menthol brands chosen by blacks than by whites. However, cigarettes with relatively lower nicotine yields, as determined by the Federal Trade Commission (FTC), are smoked more intensely. Consequently, the dose of nicotine delivered is similar among cigarette

Table 4 Determinants of smoking habits: logistic regression analyses

\begin{tabular}{lll}
\hline & \multicolumn{2}{l}{ Outcome variable } \\
\cline { 2 - 3 } & Current smoker & $\geqslant 21 \mathrm{cpd}$ \\
\hline Coefficient & $\beta(\mathrm{SE})$ & $\beta(\mathrm{SE})$ \\
Men & $-0.49(0.05)$ & $0.63(0.03)$ \\
Blacks & $0.33(0.07)$ & $-1.19(0.06)$ \\
Cases & $0.44(0.05)$ & $0.48(0.03)$ \\
Age & $-0.24(0.00)$ & $-0.05(0.00)$ \\
Years of education & $-0.01(0.01)$ & $0.00(0.00)$ \\
Current smoker & - & $-0.54(0.04)$ \\
cpd & $-0.02(0.00)$ & - \\
Years of smoking & $0.22(0.00)$ & $0.04(0.00)$ \\
Menthol & $0.11(0.06)$ & $-0.19(0.04)$ \\
\hline
\end{tabular}

brands that vary by FTC nicotine content. ${ }^{25}$ Blacks smoked fewer cigarettes per day than whites after statistical adjustment for cigarette menthol content and other factors.

Cigarette mentholation was not associated with continued smoking in blacks and in whites. Blacks were less likely than whites to have quit smoking regardless of the brand of cigarette. These findings are similar to newly published data from the Community Intervention Trial for Smoking Cessation (COMMIT). In this cohort of 13268 smokers, cigarette menthol content was not predictive of quitting in both blacks and whites after five years of follow up. ${ }^{26}$ Based on these two studies, it appears that menthol does not modify the addictive properties of cigarettes, although more population based data and physiological studies of menthol and quitting are needed to confirm this. The reason for the lower quit rate in blacks is poorly understood but could be due to lack of perceived benefits, medical advice, and social support. ${ }^{14}$ Other factors that have been suggested include targeted cigarette advertising, ${ }^{27}$ social stress, ${ }^{13}$ greater nicotine dependence, ${ }^{28}$ and other psychological reasons. ${ }^{29-31}$

The limitations of the current study include its cross sectional design and some potential biases. It used a convenience sample and not a random population based sample. Because most subjects were older adults, it is not possible to generalise the findings to younger persons. There might have been a selection bias in the smoking habits among blacks because the participating institutions were large academic medical centres that treat predominantly white populations. In New York City, blacks tend to seek cancer treatment at municipal hospitals located in minority catchment areas. Furthermore, the study was conducted for almost 20 years and the results might have been influenced by temporal changes in cigarette smoking patterns or in the formulation of mentholated cigarettes. However, when the results were stratified by three time periods, there were little differences in the PORs, with the exception of a higher inverse association between menthol and cigarette amount in blacks in the most recent years of the study. This might simply reflect variability in subgroup analyses, or possibly a trend related to social, demographic or other factors. The percentage of both black and white subjects who smoked mentholated cigarettes is lower than has been reported in national surveys that were conducted during this time period, ${ }^{16}$ but this difference could be due to the older ages of the current study subjects or to 


\section{What this paper adds}

The market share of mentholated cigarettes has increased substantially over the past several decades. In many inner urban areas, it is the most common type of cigarette smoked. Because of its cooling sensation, menthol has been shown to alter smoking inhalation patterns in comparison to non-mentholated cigarettes. Among blacks who smoke cigarettes, the lower numbers of cigarettes smoked per day and the lower quit rate compared to white smokers could be due to their preference for mentholated cigarettes. A cross sectional analysis of 19545 ever smokers found that mentholated cigarettes was not related to quitting smoking in both blacks and whites. Both blacks and white smokers of mentholated cigarettes smoked fewer cigarettes per day than smokers of other cigarettes. The findings sug gest that menthol does not increase the addictive properties of tobacco nicotine.

geographic preferences for menthol. The current data are consistent with other reports that showed blacks were about twice as likely to smoke mentholated cigarettes as whites.

It has been reported that the burning of menthol does not produce carcinogens, ${ }^{32}{ }^{33}$ although one study found that burned menthol produced polycyclic aromatic hydrocarbons. ${ }^{34}$ In experimental animals that were treated with tobacco carcinogens, menthol supplementation in their drinking water did not increase the tumour burden. ${ }^{2}$ Despite these findings, it is unknown whether tobacco sprayed with menthol might burn differently from untreated tobacco, or whether the tobacco blend of mentholated cigarettes is different. Smokers of mentholated cigarettes take fewer numbers of puffs per cigarette, but have higher levels of expired carbon monoxide. Although cigarette mentholation was not associated with an increased cancer risk in several studies, there are no studies of mentholated cigarettes and risk of cardiovascular disease.

It is well established that tobacco advertisements of specific menthol brands are targeted to young black consumers, although it remains uncertain if this is a consequence or a preference for menthol among blacks. One study ${ }^{35}$ of the content of popular magazines read primarily by blacks found that over an eight year period there were nearly 1500 tobacco advertisements. In contrast, only six of 84 articles about cancer specifically addressed lung cancer. There is a need to better understand the reasons for choosing mentholated cigarettes and how these reasons might be related to quitting success. It is unknown whether black youths would choose different brands or choose not to smoke at all if menthol cigarettes were unavailable. The cooler taste of mentholated cigarette might contribute to a false psychological perception of safety compared to non-mentholated cigarettes.

\section{ACKNOWLEDGEMENTS}

Presented at the First Conference on Menthol Cigarettes: Setting the Research Agenda. Atlanta, Georgia, 21-22 March 2002. Supported by US Public Health Service grants CA-32617, CA-68384 and CA-17613. The authors gratefully appreciate the hard work and dedication of Ms Preciosa Ong, data manager, and Ms Vicki Liang, Systems Administrator.

\section{Authors' affiliations}

J E Muscat, J P Richie Jr, S D Stellman, American Health Foundation, Valhalla, New York, USA

\section{REFERENCES}

1 Sidney S, Tekawa I, Friedman GD. Mentholated cigarette use among multiphasic examinees, 1979-1986. Am J Public Health 1989;79:1415-6.

2 Richie JP Jr, Carmella SG, Muscat JE et al. Differences in the urinary metabolites of the tobacco-specific lung carcinogen 4-(methylnitrosamino)-1-(3-pyridyl)-1-butanone in black and white smokers. Cancer Epidemiol Biomarkers Prev 1997;6:783-90.
3 Cummings KM, Giovino G, Mendicino AJ. Cigarette advertising and black-white differences in brand preference. Public Health Rep 1987; 102:698-701.

4 Jarvik ME, Tashkin DP, Caskey NH, et al. Mentholated cigarettes decrease puff volume of smoke and increase carbon monoxide absorption. Physiol Behav 1994;56:563-70.

5 McCarthy WJ, Caskey NH, Jarvik ME, et al. Menthol vs nonmenthol cigarettes: effects on smoking behavior. Am J Public Health 1995;85:67-72

6 Miller GE, Jarvik ME, Caskey NH, et al. Cigarette mentholation increases smokers' exhaled carbon monoxide levels. Exp Clin Psychopharmacol 1994;2:154-60.

7 Clark PI, Gautam S, Gerson LW. Effect of menthol cigarettes on biochemical markers of smoke exposure among black and white smokers. Chest 1996;110:1194-8.

8 Hebert JR, Kabat GC. Menthol cigarette smoking and oesphoageal cancer. Int J Epidemiol 1989;18:37-44.

9 Kabat GC, Hebert JR. Use of mentholated cigarettes and lung cancer risk. Cancer Res 1991;51:6510-3.

10 Kabat GC, Hebert JR. Use of mentholated cigarettes and oropharyngeal cancer. Epidemiology 1994;5: 183-8.

11 Sidney S, Tekawa IS, Friedman GD, et al. Mentholated cigarette use and lung cancer. Arch Intern Med 1995; 155:727-32.

12 Carpenter CL, Jarvik ME, Morgenstern $\mathrm{H}$, et al. Mentholated cigarette smoking and lung-cancer risk. Ann Epidemiol 1999;9:114-20.

13 Novotny TE, Warner KE, Kendrick JS, et al. Smoking by blacks and whites: socioeconomic and demographic differences. Am J Public Health 1988;78: $1187-9$

14 Orleans CT, Schoenbach VJ, Salmon MA, et al. A survey of smoking and quitting among black Americans. Am J Public Health 1989;79:176-81.

15 Kabat GC, Morabia A, Wynder EL. Comparison of smoking habits of blacks and whites in a case-control study. Am J Public Health 1991;81:1483-6.

16 US Department of Health and Human Services. Tobacco use among U.S. racial/ethnic minority groups: African Americans, American Indians and Alaska Natives, Asian Americans and Pacific Islanders, Hispanics. A report of the Surgeon General, 1998. Atlanta, Georgia: Centers for Disease Control and Prevention, Office on Smoking and Health, 1998. (US Government Printing Office Publication No S/N 017-001-00527-4.)

17 Wagenknecht LE, Cutter GR, Haley NJ, et al. Racial differences in serum cotinine levels among smokers in the Coronary Artery Risk Development in (Young) Adults Study. Am J Public Health 1990;80: 1053-6.

18 Caraballo RS, Giovino GA, Pechacek TF, et al. Racial and ethnic differences in serum cotinine levels of cigarette smokers: Third National Health and Nutrition Examination Survey, 1988-1991. JAMA 1998;280: 135-9

19 Perez-Stable EJ, Herrera B, Jacob P III, et al. Nicotine metabolism and intake in black and white smokers. JAMA 1998;280:152-6.

20 Pickworth WB, Moolchan ET, Berlin I, et al. Sensory and physiological effects of menthol and non-menthol cigarettes with differing nicotine delivery. Pharmacol Biochem Behav 2002;71:55-61

21 Hymowitz N, Cummings KM, Hyland A, et al. Predictors of smoking cessation in a cohort of adult smokers followed for five years. Tobacco Control 1997:6:S57-62

22 Osler M, Prescott E, Godtfredsen N, et al. Gender and determinants of smoking cessation: a longitudinal study. Prev Med 1999;29:57-62.

23 Stellman SD, Resnicow K.Tobacco smoking, cancer and social class. IARC Sci Publ 1997;138:229-50.

24 Stellman SD, Muscat JE, Thompson S, et al. Risk of squamous cell carcinoma and adenocarcinoma of the lung in relation to lifetime filter cigarette smoking. Cancer 1997;80:382-8.

25 Diordjevic MV, Stellman SD, Zang E. Doses of nicotine and lung carcinogens delivered to cigarette smokers. J Natl Cancer Inst 2000;92:106-11.

26 Hyland A, Garten S, Giovino GA, et al. Mentholated cigarettes and smoking cessation. Findings from COMMIT. Tobacco Control 2002;11:135-9.

27 Moore DJ, Williams JD, Qualls WJ. Target marketing of tobacco and alcohol-related products to ethnic minority groups in the United States. Ethn Dis 1996:6:83-98.

28 Royce JM, Hymowitz N, Corbett K, et al. Smoking cessation factors among African Americans and whites. COMMIT research group. Am J Public Health 1993;83:220-6.

29 Son BK, Markovitz JH, Winders S, et al. Smoking and nicotine dependence, and depressive symptoms in the CARDIA study. Effects of educational status. Am J Epidemiol 1997;145:110-6.

30 Kandel DB, Chen K. Extent of smoking and nicotine dependence in the United States: 1991-1993. Nicotine Tobacco Research 2000;2:263-74.

31 Andreski P, Breslau N. Smoking and nicotine dependence in young adults: differences between blacks and whites. Drug Alcohol Depend 1993;32:119-25.

32 National Cancer Institute. Bioassay of DL-menthol for possible carcinogenicity. National Cancer Institute Carcinogenesis Technical Report, series no. 1979;98,1-123

33 Jenkins RWJ, Newman RH, Chavis MK. Cigarette smoke formation studies II. Smoke distribution and mainstream pyrolytic composition of added 14C-menthol(U). Beitr Tabakforsch 1970;5:299-301.

34 Schmeltz I, Schlotzhaver WS. Benzo(a)pyrene, phenols and other products from pyrolysis of the cigarette additive, $(d, 1)$-menthol. Nature 1968;219:370-1.

35 Hoffman-Goetz L, Gerlach KK, Marino C, et al. Cancer coverage and tobacco advertising in African-American women's popular magazines. $J$ Community Health 1997;22:261-70. 